\title{
HORVÁTORSZÁGI MAGYAR OKTATÁSI ÉS MÜVELŐDÉSI KÖZPONT
}

Horvátországi Magyar Oktatási és Művelődési Központ

Cím: Eszék, Drinska utca 12/A

Honlap: http://www.centar-prosvjetnokulturni-madjara-os.skole.hr/HU/index.html

E-mail: hmomk@pkcm.hr

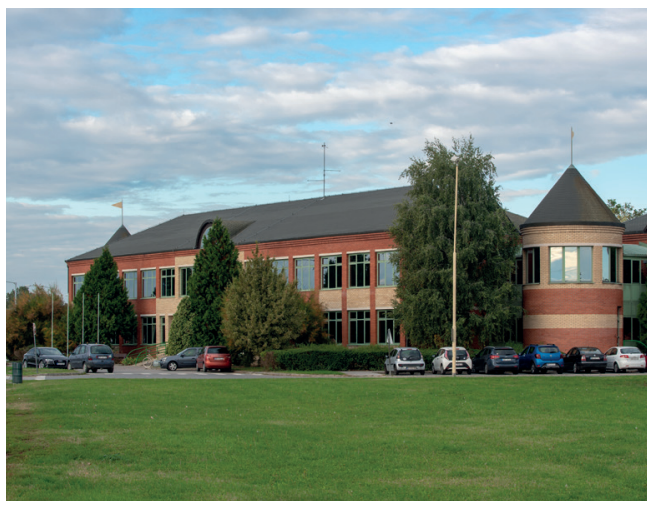

A horvátországi magyarság oktatási zászlóshajója Eszéken működik. Szlavónia „fővárosában" 1999-ben nyitotta meg kapuit a Horvátországi Magyar Oktatási és Múvelődési Központ, amelynek keretein belül óvoda, általános iskola és középiskola is múködik. Az óvodába és az általános iskolába főleg szlavóniai diákok járnak, míg a középiskolában Szlavónia és a horvátországi Baranya fiataljai egyaránt megtalálhatóak. Középiskolai szinten gimnázium, közgazdasági szak, hotel-turizmus, szakács és kereskedő szakok között választhatnak a diákok a nyolcadik osztály befejezése után. Az oktatási intézmény az ún. „A" modell szerint múködik, ami azt jelenti, hogy a horvát programot magyar nyelven oktatják a tanárok. Az általános iskolás könyvek magyar nyelvűek, amelyeket a Horvátországi Magyar Oktatási és Múvelődési Központ és más magyar tannyelvǔ iskolák munkatársai fordítottak magyarra. A horvátországi magyarság oktatási csúcsintézményének megalapításakor múvelődési funkciót is megfogalmaztak, aminek csak 2017 óta tud megfelelni az intézmény - az illetékes horvát minisztérium azóta biztosít múvelődésszervezőt. Az intézmény keretei között 2019-ben felépült a Diákotthon is, amellyel a horvát állam két évtizedes adósságát törlesztette az itteni magyarság felé. Az ügy fontosságát és szimbolikáját jelzi, hogy a megnyitón részt vett mind a két ország miniszterelnöke. A Diákotthon megnyitása új perspektívát nyújt, hiszen Horvátország távolabbi részéből is érkezhetnek diákok tanulni.

Pozitív diszkrimináció jellemzi a horvát politikát, hiszen nagyon kis létszámú osztályok indítását is engedélyezik, ami egyfajta magániskola jelleget is kölcsönöz az intézménynek. Ezt ismerik fel a többségi nemzet tagjai, és mind többen íratják be az általános iskola első osztályába gyermekeiket. A kitűnő felszereltség, a képzett tanári kar, mind

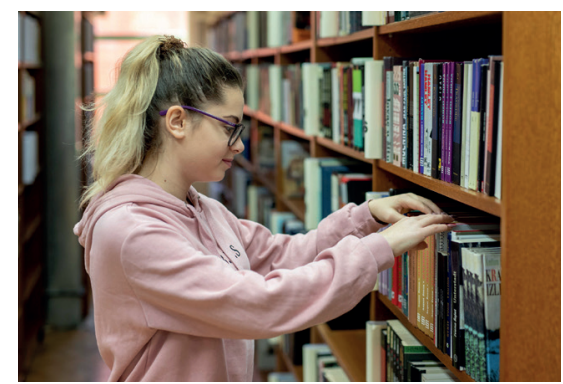


biztosíték arra, hogy Horvátországban magyarnak és horvátnak egyaránt kiváló oktatási intézmény áll a rendelkezésére.

A Horvátországi Magyar Oktatási és Művelődési Központ könyvtára és olvasóterme a térségben zajló oktatási-nevelési folyamatok szerves része. Feladatát a felhasználókkal folytatott közvetlen munkájával, a rendelkezésükre bocsátott információs tartalmakkal és forrásokkal végzi. A könyvtári tevékenységeknek egy $115 \mathrm{~m}^{2}$-es helyiség ad otthont, a könyvtár állományát pedig 7464 kötet és 186 audiovizuális egység alkotja. A könyvtárat az általános és a középiskolás korosztály, a szülők és az intézmény munkatársai egyaránt látogatják.

A könyvtár kommunikációjában és tevékenységének megszervezésében szakspecifikus megközelítést alkalmaz: rendszeresen felméri a felhasználói igényeket, az információk célzott és minőségi feldolgozását pedig sokoldalú (részben digitális) készségekkel és ismeretekkel támogatja. Dorkić Diana, okleveles könyvtáros, valamint horvát nyelv és irodalom szakos tanár, 2007 óta vezeti az intézmény könyvtárát.

A kortárs társadalom alapvető elvárása az információs műveltség, amely mind a klasszikus ismeretforrások, mind az új média közegében lehetővé teszi az információk befogadását és alkalmazását. Hosszú távú tervünk, hogy a könyvtárat mint dinamikus alkotóteret közelebb hozzuk a „Z generáció”-hoz, és sokrétű kommunikációs eszköztárral segítsük a generáció tagjainak önkifejezését. Ezt szem előtt tartva olyan multimediális teret hoztunk létre, ahol a hagyományos könyv formátumú angyagok, illetve az új média által közvetített tartalmak biztosításával, továbbá korszerű oktatási módszerekkel fejlesztjük a tanulók vonatkozó készségeit és kompetenciáit, kritikai érzékét, valamint polgári felelősségtudatát az információk felkutatása, értékelése és alkalmazása során.

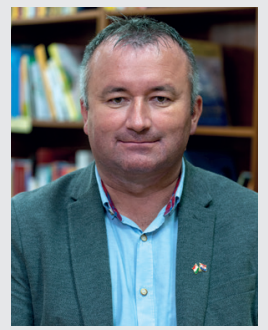

Andócsi János

Andócsi János 2000-ben végzett az Eötvös Loránd Tudományegyetem Bölcsészettudományi Karán, történelem szakirányon. Egy évre rá szerzett abszolutóriumot az ELTE Állam- és Jogtudományi Karán politológia szakon. 2001-ben a Századvég Politikai Iskola politikai kommunikáció szakán abszolvált. Ugyanebben az évben fejezte be az egri Eszterházy Károly Főiskola felsőfokú újságíró képzését. 2002 óta a Horvátországi Magyar Oktatási és Művelődési Központban etikát, történelmet és politikát oktat, jelenleg a központ igazgatója. 2003 óta a Hercegszőlősi Magyar Kisebbségi Önkormányzat elnöke, illetve tagja Eszék-Baranya megye Magyar Kisebbségi Önkormányzatának. 2003 óta fő- és felelős szerkesztője a Horvátországi Magyarság címú havilapnak. 